\title{
Muslim customer perceived value on customer satisfaction and loyalty: Religiosity as a moderation
}

\author{
Yayuk Sri Rahayu $^{a^{*}}$, Margono Setiawan ${ }^{\mathrm{b}}$, Dodi Wirawan Irawanto ${ }^{\mathrm{b}}$ and Mintarti Rahayu ${ }^{\mathrm{b}}$
}

${ }^{a}$ Faculty of Economic Universitas Islam Negeri Maulana Malik Ibrahim, Indonesia

${ }^{b}$ Faculty of Economic and Business Brawijaya University, Indonesia

\section{H R O N I C L E}

\section{Article history:}

Received: September 232019

Received in revised format:

October 292019

Accepted: November 8, 2019

Available online:

November 8, 2019

Keywords:

Religiosity

Muslim customer perceived value

Customer satisfaction

Customer loyalty

\section{A B S T R A C T}

This study aims to determine the effect of Muslim customer perceived value on customer satisfaction and customer loyalty of sharia banking and religiosity role in moderating the existing effect. The study population includes all customers of Sharia banking. Total samples of 104 respondents are selected by accidental sampling technique. To know and to test the research hypothesis, data are analyzed by partial least square (PLS). This study has four results. First, the Muslim customer perceived value (MCPV) variable directly affects customer satisfaction. It consists of price, emotional values, and social values variables. While the quality, Islamic physical attributes, and Islamic non-physical attributes variables directly do not affect satisfaction of Islamic banking customers. Second, Muslim customer perceived value (MCPV) variable directly affects customer loyalty. It consists of price, emotional value, physical and non-physical attributes of Islam. Moreover, quality and social value variables directly do not affect loyalty of sharia banking customers. Third, satisfaction only mediates the effect of price, emotional value, and social value variables on the loyalty of sharia banking customers. Satisfaction does not mediate the effect of quality, Islamic physical attributes, and Islamic nonphysical attributes affect the loyalty of sharia banking customers. Forth, Religiosity does not moderate the effect of Muslim customer perceived value (MCPV) variable, namely Islamic physical attributes and Islamic nonphysical attributes, on satisfaction of sharia banking customers.

\section{Introduction}

Sharia banking system operates based on profit sharing principles (Famiyeh et al., 2018; Farrag \& Hassan, 2015). It provides an alternative for a mutually beneficial banking system for community and banks, and highlights the aspects of fairness in transactions, ethical investments, putting together the values of togetherness and brotherhood in production, and avoids speculative activities in financial transactions. Providing a diverse range of banking products and services with a more varied financial scheme makes Sharia banking become an alternative for a credible banking system that can be enjoyed by all Indonesians without exception. Based on demands of high service quality performance, customers have high expectations to service quality performance (Rahman et al., 2018). There is still a gap between service performances received with services expected by customer. Islamic banking customers judge that service quality received is still below their expectations (Rahayu, 2015). Kotler and Keller (2007) stated that services quality is a form of consumer assessment on services level received (perceived services) and expected level of services (expected services). The concept of service quality relies on satisfying the desires or demands of customers based on their expectations. To win competition, banks must provide more value for customers in the form of quality services. The quality attribute has become a highly considered element in consumer valuation of bank (Al-Mutawa \& Ibrahim, 2013). The customer value is the difference between total customer value and total customer cost. The total customer value is a set of benefits expected by customer of a particular product or service and total customer cost is the set of costs expected by consumer to evaluate, obtain, use and dispose to get the products or services (Kotler \& Keller, 2007). Sweeney and Soutar (2001) in Chen and Lin (2014) stated that perceived value consists of several dimensions including functional, social, emotional, epistemic, and conditional values. Carlos Fandos Roig et al. (2006) suggested that

* Corresponding author. Tel.: +8121695653

E-mail address: yayuk@pbs.uin-malang.ac.id (Y.S. Rahayu) 
customer perceived value in banking services includes functional value development, functional value of personnel, functional value of service, functional value of price, emotional value, and social value. Mahmoud and Abduh (2014) stated that perceived value positively affects interest to support Sharia banking in Russia. Rasyeed and Abadi (2014) stated that there is a significant relationship between perceived value and consumer loyalty. Chang and Wang (2011) argued that customer perceived value affects customer satisfaction and loyalty. Rahayu (2016) stated that there are three variables to affect partially on customer satisfaction, namely emotional value, social value, and Islamic nonphysical attribute. The other three variables of quality, price, and Islamic physical attributes have no partial effect on customer satisfaction. One concept development of customer perceived value is Muslim customer perceived value (MCPV). It can be applied to Sharia banking industry as recommended by Eid and Ghohary (2015). During this time the concept has been applied at Muslim countries in Middle East. Sharia banking industry in Indonesia has largest Muslim consumers and largest potential market that has not been serviced well. Some Muslim societies are even fanatical to choose Islamic banks with profit sharing rule, not interest or usury. But on other hand, growth rate of Sharia banking in Indonesia is very slow compared with conventional banking growth rate. There is still a lack of research to specialize in concepts and values of Muslim consumers becomes the basis for further research in order to test and develop the existing concepts. Mokhlis (2009) stated that Muslim consumers have unique characteristics when they decide to buy anything, they always consider the doctrine of their religion, which is Islam. Furthermore, religiosity is recognized as one most important culture to influence on consumers' behavior (Ied, 2013; Zamani-Farahani \& Henderson, 2010; Zamani-Farahani \& Moses, 2012). Rehman and Shahbaz Shabbir (2010) reported that religiosity affects the adoption of new products by Muslim consumers through their beliefs about what products they should adopt. Religiosity also has a significant role to affect consumer and social behavior (Khraim, 2010; Mukhtar \& But, 2012). In addition, research by AbouYoussef et al. (2015) on Islamic banking in Egypt stated that religiosity affected the attitude of consumers of sharia banking in Egypt. Religiosity also moderates the effect of perceived value on customer satisfaction (Eid \& Gohary, 2015; Eid, 2015). In addition, Souiden and Rani (2015) stated that religiosity has an indirect effect on interest of sharia banking purchase through attitudes toward the bank. However, Farraq and Hassan (2015) found different results with some previous researches that there was a negative relationship between religiosity with attitude of Egyptian youth in determining fashion trends. Previous researches results showed the differences in those results, especially religiosity and the effect on customer satisfaction and behavior. This provides a research gap for this study to examine deeper about the religiosity role to influence consumer satisfaction and behavior. This study aims to determine the effect of Muslim customer perceived value on customer satisfaction and customer loyalty of sharia banking and religiosity role to moderate the existing effect.

\section{Hypotheses Model}

The hypotheses model of this research can be illustrated at Fig. 1.

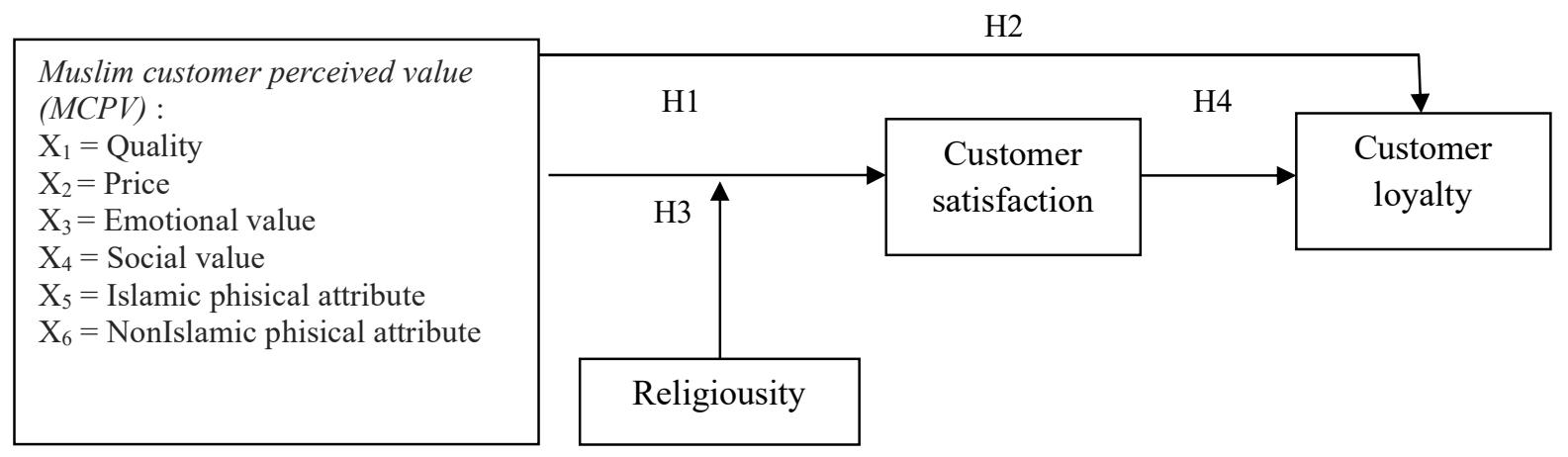

Fig. 1. Hypothesis Model

Muslim customer perceived value affect customer satisfaction (Chang \& Wang, 2011). The development of Muslim customer perceived value (MCPV) model was pioneered by Eid and Gohary and they showed that six dimensions of MCPV have positive effects on Muslim consumer satisfaction (Eid \& Gohary, 2015). Adversely, three variables affect customer satisfaction (Rahayu, 2016). They are emotional value, social value, and Islamic nonphysical attributes. The other three variables of quality, price, and Islamic physical attributes have no effect on satisfaction. Based on above description, the first hypothesis is formulated below.

Hypotheses 1: Muslim customer perceived value (MCPV) has a significant effect on customer satisfaction.

Chang and Wang (2011) showed a significant relationship between perceived value and consumer loyalty. Based on above description, the second hypothesis is formulated below.

Hypotheses 2: Muslim customer perceived value (MCPV) has a significant effect on customer loyalty.

Research results found that religiosity moderates the effect of Muslim customer perceived value on customer satisfaction by strengthening the effect of Islamic physical attributes and Islamic non-physical attribute on customer satisfaction (Eid \& Gohary, 2015). Based on description above, the third hypothesis is formulated below. 
Hypotheses 3: Religiosity moderates the effect of Muslim customer perceived value (MCPV) on customer satisfaction.

PAKSERV has an indirect effect on consumer loyalty through satisfaction. Satisfaction mediates the effect of perceived value on loyalty. Based on above description, the fourth hypothesis is formulated below.

Hypotheses 4: Satisfaction mediates the effect of Muslim customer perceived value (MCPV) on loyalty.

The study population includes all customers of Sharia banking at East Java- Indonesia. Total samples of 104 respondents are selected by accidental sampling technique.

Muslim customer perceived value (MCPV) consists of some dimensions (Eid \& Gohary, 2015). Quality is ability of a good / service to deliver results / performance that match or exceed the customer wants. Price is the amount of money that must be paid by customer to get a product. Emotional value is a feeling of emotional attachment between the consumer and purchased product. Consumers are comfortable with what they buy. Social value is a consumer feeling accepted by his social environment when he buys a product. Islamic physical attributes include the availability of worship facilities (sholat), appearance of employees in accordance with Islamic norms, availability of halal food and beverages, availability of holy Qur'an in places of worship, and availability of toilets in accordance with Islamic Sharia rules. Islamic nonphysical attributes consist of availability of separate services, availability of products in accordance with sharia, availability of Islamic music, greetings, and others. Customer satisfaction is the level of consumer feeling after comparing between what he receives and his expectations (Kotler \& Keller, 2007). Consumer loyalty is a customer's commitment to a brand, store or supplier based on a very positive nature in long-term purchases (Eid \& Gohary, 2015). Religiosity is defined as how far the knowledge, beliefs, worship and implementation rules and appreciation of religion embraced (Eid \& Gohary, 2015). To know and test the research hypotheses, data is analyzed by partial least square (PLS). This study Respondents consisted of 60 men and 44 women, minimum age is 15 years old, majority are students and private employees, and majority become customers of sharia banking less than 2 years $(46.2 \%)$.

\section{Hypotheses testing}

Hypotheses testing results with PLS software are shown in Fig. 2 and Table 1.

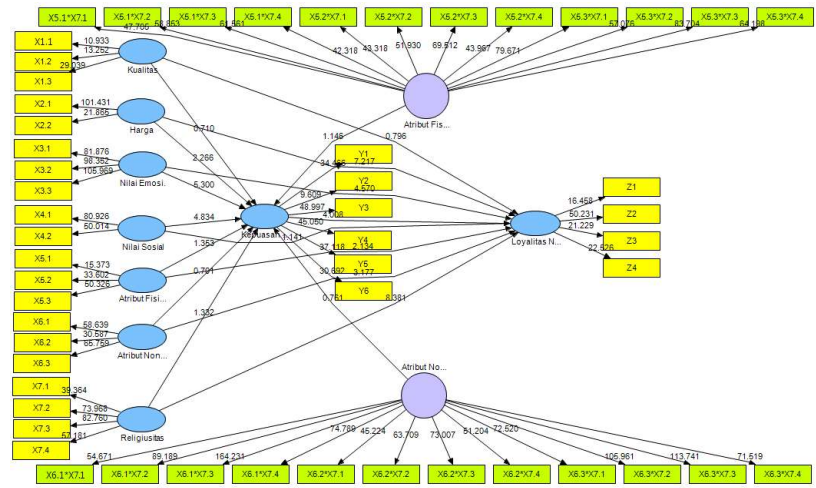

Fig. 2. Hypotheses test

Table 1

Direct Effect Test

\begin{tabular}{|c|c|c|c|c|c|c|}
\hline & $\begin{array}{c}\text { Original } \\
\text { Sample (O) }\end{array}$ & $\begin{array}{c}\text { Sample } \\
\text { Mean (M) }\end{array}$ & $\begin{array}{l}\text { Standard } \\
\text { Deviation } \\
\text { (STDEV) }\end{array}$ & $\begin{array}{c}\text { Standard } \\
\text { Error } \\
\text { (STERR) }\end{array}$ & $\begin{array}{c}\text { T Statistics } \\
(\mid \text { O/STDEV } \mid)\end{array}$ & Description \\
\hline Quality $\rightarrow$ Customer Satisfaction & -0.037 & -0.030 & 0.052 & 0.052 & 0.624 & Insignificant \\
\hline Price $\rightarrow$ Customer Satisfaction & 0.083 & 0.081 & 0.037 & 0.037 & 2.266 & Significant \\
\hline Emotional Value $\rightarrow$ Customer Satisfaction & 0.211 & 0.208 & 0.040 & 0.040 & 5.300 & Significant \\
\hline Social Value $\rightarrow$ Customer Satisfaction & 0.204 & 0.202 & 0.042 & 0.042 & 4.834 & Significant \\
\hline Islamic Physical Attribute $\rightarrow$ Customer Satisfaction & 0.318 & 0.333 & 0.235 & 0.235 & 1.353 & Insignificant \\
\hline Non Islamic Physical Attribute $\rightarrow$ Customer Satisfaction & 0.138 & 0.144 & 0.197 & 0.197 & 0.701 & Insignificant \\
\hline Religiosity $\rightarrow$ Customer Satisfaction & 0.263 & 0.295 & 0.198 & 0.198 & 1.332 & Insignificant \\
\hline Customer Satisfaction $\rightarrow$ Customer Loyalty & 0.219 & 0.217 & 0.036 & 0.036 & 4.008 & Significant \\
\hline Quality $\rightarrow$ Customer Loyalty & -0.044 & -0.046 & 0.055 & 0.055 & 0.796 & Insignificant \\
\hline Price $\rightarrow$ Customer Loyalty & 0.265 & 0.267 & 0.037 & 0.037 & 7.217 & Significant \\
\hline Emotional Value $\rightarrow$ Customer Loyalty & 0.209 & 0.209 & 0.046 & 0.046 & 4.570 & Significant \\
\hline Social Value $\rightarrow$ Customer Loyalty & -0.041 & -0.036 & 0.055 & 0.055 & 1.141 & Insignificant \\
\hline Islamic Physical Attribute $\rightarrow$ Customer Loyalty & 0.079 & 0.083 & 0.037 & 0.037 & 2.134 & Significant \\
\hline Non Islamic Physical Attribute $\rightarrow$ Customer Loyalty & -0.136 & -0.137 & 0.043 & 0.043 & 3.177 & Significant \\
\hline
\end{tabular}


Fig. 2 and Table 1 show that Muslim customer perceived value (MCPV) variable has a direct effect on customer satisfaction. It consists of price, emotional values, and social values. While the quality, Islamic physical attributes, and Islamic non-physical attributes variables directly do not affect the satisfaction of Islamic banking customers. Muslim customer perceived value (MCPV) variable directly affects customer loyalty. It consists of price, emotional value, Islamic physical attributes, and Islamic non-physical attributes. While the quality and social value variables directly do not affect loyalty of sharia banking customers. Table 2 shows the results of indirect effect test.

Table 2

Indirect effect test

\begin{tabular}{|c|c|c|c|c|c|c|c|}
\hline Path & $\mathbf{A}$ & B & SEA & SEB & T-Statistics & Sig & Description \\
\hline Quality $\rightarrow$ Customer Satisfaction $\rightarrow$ Customer Loyalty & -0.037 & 0.219 & 0.052 & 0.036 & -0.7067 & 0.480 & Insignificant \\
\hline Price $\rightarrow$ Customer Satisfaction $\rightarrow$ Customer Loyalty & 0.083 & 0.219 & 0.037 & 0.036 & 2.1047 & 0.035 & Significant \\
\hline Emotional Value $\rightarrow$ Customer Satisfaction $\rightarrow$ Customer Loyalty & 0.211 & 0.219 & 0.040 & 0.036 & 3.9854 & 0.000 & Significant \\
\hline Islamic Physical Attribute $\rightarrow$ Customer Satisfaction $\rightarrow$ Customer Loyalty & 0.318 & 0.219 & 0.235 & 0.036 & 1.3209 & 0.187 & Insignificant \\
\hline Non Islamic Physical Attribute $\rightarrow$ Customer Satisfaction $\rightarrow$ Customer Loyalty & 0.138 & 0.219 & 0.197 & 0.036 & 0.6959 & 0.486 & Insignificant \\
\hline Religiosity $\rightarrow$ Customer Satisfaction $\rightarrow$ Customer Loyalty & 0.263 & 0.219 & 0.198 & 0.036 & 1.2977 & 0.194 & Insignificant \\
\hline
\end{tabular}

Table 2 shows that satisfaction only mediates the effect of price, emotional value, and social value variables on loyalty of sharia banking customers. Satisfaction does not mediate the effect of quality, Islamic physical attributes, and non-physical attributes of Islam on loyalty of sharia banking customers. The moderation test results are shown in Table 3.

Table 3

Moderation test

\begin{tabular}{|c|c|c|c|c|c|c|}
\hline & $\begin{array}{c}\text { Original Sam- } \\
\text { ple (O) }\end{array}$ & $\begin{array}{c}\text { Sample } \\
\text { Mean (M) }\end{array}$ & $\begin{array}{c}\text { Standard Devia- } \\
\text { tion (STDEV) }\end{array}$ & $\begin{array}{c}\text { Standard Error } \\
\text { (STERR) }\end{array}$ & $\begin{array}{c}\text { T Statistics } \\
\text { (|O/STDEV } \mid)\end{array}$ & Description \\
\hline $\begin{array}{l}\text { Islamic Physical Attribute*Religiosity } \rightarrow \text { Cus- } \\
\text { tomer Satisfaction }\end{array}$ & -0.374 & -0.399 & 0.326 & 0.326 & 1.146 & Insignificant \\
\hline
\end{tabular}

Table 3 shows that Religiosity does not moderate the effect of Muslim customer perceived value (MCPV) variable, namely the Islamic physical attributes and Islamic non-physical attributes of Islam, on satisfaction of Islamic banking customers.

\section{Discussion}

\subsection{The effect of Muslim customer perceived value on customer satisfaction}

Muslim customer perceived value (MCPV) variable directly affects customer satisfaction. It consists of price, emotional values, and social values. While the quality, Islamic physical attributes, and Islamic non-physical attributes directly do not affect satisfaction of Islamic banking customers. This is consistent with several previous studies of Eid and Gohary (2015) and Rahayu (2016) who found that price, emotional values, and social values variables affect consumer satisfaction. But on other hand, the results of this study also are not consistent with Eid and Gohary (2015) that quality, Islamic physical attributes, and Islamic non-physical attributes variables directly affect consumer satisfaction but this study results shows three variables directly have no effect on sharia banking customers.

This study results are inconsistent with Eid and Hatem (2015) who found that six dimensions of Muslim Customer Perceived Value (MCPV) consisted of quality, price, emotional value, social values, Islamic attributes and Islamic non-physical attribute have positive effects on Muslim consumer satisfaction. In addition, these study results are also different from Saputro (2013) and Widiarso (2011) who found that perceived value affects consumer satisfaction. The variables that do not affect customer satisfaction can be caused by differences in respondents characteristics in this study. Islamic banking customers in Malang have not seen Islamic quality and physical attributes as very important because banks have almost had the same standards for both of them. Some indicators of Islamic physical attributes such as the availability of prayer rooms are not considered important because customers who use these services are very rare. Usually customers come to bank in a relatively short time because the standard bank services also fast and few customers arrive at sharia banking office. Likewise, indicators of Islamic bank employee's appearance in accordance with sharia are considered not too important because this has become the obligation of all Islamic banking employees. They work in an institution labeled sharia, so it is natural to look appearance in accordance with sharia. In addition, respondents' characteristics show that the majority were young people aged 15-25 years and they were students who were sharia banking customer for less than 2 years. This can affect their judgment so it also affects this study results. Respondents with these characteristics rarely come directly to sharia banking office, they often only come to ATM. They come to bank office only if there are urgent events such as reporting ATM or losses, and failed ATM transactions (based on results of interviews with several respondents and observations at sharia banking office). This can become a limitation of this study. Therefore, future researchers should more selective to choose respondents in order truly representative. 
These study results indicate that Muslim customer perceived value (MCPV) variable that directly affects customer loyalty consists of price, emotional value, Islamic physical attributes, and Islamic non-physical attributes. While quality and social value variables directly do not affect loyalty of sharia banking customers. The result is slightly different with Rahayu (2016) that partially there are only two variables to affect loyalty, namely price and emotional value while the other four variables of quality, social value, Islamic physical attributes, and non-physical attributes Islam had no effect. This is the study novelty because it has not been studied by previous researchers. These results can be considered reasonable because in theory loyalty achievement must be begun with satisfaction (Kotler \& Keller, 2007). Stage in consumer behavior after making a purchase a product is assessment of performance to expectation, it will create satisfaction or dissatisfaction. Satisfied consumers will repurchase, convey positive things about the product, and not move to another product, it is an indicator of consumer loyalty.

\subsection{The role of customer satisfaction as a mediation the effect of Muslim customer perceived value on customer loyalty}

This study results found that satisfaction only mediates the effect of price, emotional value, and social value variables on loyalty of sharia banking customers. Satisfaction does not mediate the effect of quality, Islamic physical attributes, and Islamic non-physical attributes variables on loyalty of sharia banking customers. This is inconsistent with Rahayu (2016) that satisfaction becomes a mediation variable of quality, Islamic physical attributes, and Islamic non-physical attributes on loyalty of sharia banking customers in Malang City. These three variables have an indirect effect on loyalty through customer satisfaction. While for other three variables, namely price, emotional value, and social value directly affect customer loyalty without mediated by satisfaction variable. These results support Widiarso (2011) that perceived value affects brand loyalty through customer satisfaction. These results are consistent with theory that to achieve customer loyalty, consumers must be satisfied (Kotler \& Keller, 2007).

\subsection{The role of religiosity as a moderation the effect of Muslim customer perceived value on customer satisfaction}

This study results show that religiosity does not moderate the effect of Muslim customer perceived value (MCPV), namely the physical attributes of Islam and non-physical attributes of Islam, on satisfaction of Islamic banking customers. This finding is inconsistent with Eid and Gohary (2015) that Islamic religiosity has a moderation effect of Islamic physical attributes and Islamic non-physical attributes on satisfaction of Muslim customers. Other findings reinforce the importance of religiosity to understand the satisfaction and behavior of Muslim customers. Likewise, Rahayu and Fitriyah's (2017) research showed that religiosity moderates the effect of one Muslim customer perceived value (MCPV) variable on Islamic banking customer satisfaction, namely Islamic nonphysical attribute variables strengthen the existing effects. In addition, respondent characteristics also affect the results. Study results show that majority of respondents are young students and affecting the respondents' comprehension to religiosity. Generally, young people at 15-25 years old do not too concern to understanding level of their religion. They do religion teachings only as formalities to abolish obligations, without full awareness that all of them are obligations and forms of devotion to their religion. Interviews and observation results show that student respondents decided to choose sharia banking customers not because of their religiosity but more because of schools or colleges that required to open accounts in Islamic banking or in order to fulfil their duties. This causes their relationship with Islamic banking are bland because their consciousness does not arise from the heart. For this reason, Islamic banking must increase the level of socialization and good relations with this youth segment to increase their awareness to participate in developing Islamic banking and Islamic economy. This segment cannot be underestimated because in next few years they will make a full decision on their lives and their numbers are also very large. This youth segment is a very potential market for Islamic banking in future that must be embraced early.

\section{Research Limitations}

The MCPV concept is relatively new and has not been widely applied in research. This study uses all customer banking services in Malang City and most of them are students whose the relationships with sharia bank office is relatively low.

\section{Conclusion and suggestion}

Muslim customer perceived value (MCPV) variable directly affects customer satisfaction. It consists of price, emotional values, and social values. While the quality variables, Islamic physical attributes, and Islamic non-physical attributes directly do not affect satisfaction of sharia banking customers. Muslim customer perceived value (MCPV) variable directly affects customer loyalty. It consists of price, emotional value, Islamic physical attributes, and Islamic non-physical attributes. While the quality and social value variable directly do not affect loyalty of sharia banking customers. Religiosity does not moderate the effect of Muslim customer perceived value (MCPV) variable, namely the Islamic physical attributes and Islamic non-physical attributes, on satisfaction of Islamic banking customers. Satisfaction only mediates the effect of price, emotional value, and social value variables on loyalty of sharia banking customers. Satisfaction does not mediate the effect of quality, Islamic physical attributes, and Islamic non-physical attributes variables on loyalty of sharia banking customers. 
Future researchers should develop another concept of Muslim customer behavior such as Muslim customer satisfaction and Muslim customer loyalty. In addition, the indicators determination should also be done more carefully. Future researchers should more focus on one Sharia bank and should use case study research.

\section{References}

Abou-Youssef, M. M. H., Kortam, W., Abou-Aish, E., \& El-Bassiouny, N. (2015). Effects of religiosity on consumer attitudes toward Islamic banking in Egypt. International Journal of Bank Marketing, 33(6), 786-807.

Al-Mutawa, S. A., \& Ibrahim, M. E. (2013). Effects of Gender and Personality Traits of Front-Desk Employees on Customers' Assessment of Service Quality: Evidence from Islamic Banks in the UAE. International Journal of Business and Management, 8(15), 1.

Carlos Fandos Roig, J., Sanchez Garcia, J., Angel Moliner Tena, M., \& Llorens Monzonis, J. (2006). Customer perceived value in banking services. International Journal of Bank Marketing, 24(5), 266-283.

Chen, S. C., \& Lin, C. P. (2015). The impact of customer experience and perceived value on sustainable social relationship in blogs: An empirical study. Technological Forecasting and Social Change, 96, 40-50.

Hsin Chang, H., \& Wang, H. W. (2011). The moderating effect of customer perceived value on online shopping behaviour. Online Information Review, 35(3), 333-359.

Eid, R. (2015). Integrating Muslim customer perceived value, satisfaction, loyalty and retention in the tourism industry: An empirical study. International Journal of Tourism Research, 17(3), 249-260.

Eid, R., \& El-Gohary, H. (2015). The role of Islamic religiosity on the relationship between perceived value and tourist satisfaction. Tourism Management, 46, 477-488.

Famiyeh, S., Asante-Darko, D., \& Kwarteng, A. (2018). Service quality, customer satisfaction, and loyalty in the banking sector: The moderating role of organizational culture. International Journal of Quality \& Reliability Management, 35(8), 1546-1567.

Farrag, D. A., \& Hassan, M. (2015). The influence of religiosity on Egyptian muslim youths' attitude towards fashion. Journal of Islamic Marketing, 6(1), 95-108.

Khraim, H. (2010). Measuring religiosity in consumer research from an Islamic perspective. Journal of Economic and Administrative Sciences, 26(1), 52-78.

Kotler, P., \& Keller, K. L. (2007). A framework for marketing management. Upper Saddle River, NJ: Prentice Hall.

Mahmoud, L. O. M., \& Abduh, M. (2014). The role of awareness in Islamic bank patronizing behavior of mauritanian: An application of TRA. Journal of Islamic Finance, 176(3192), 1-9.

Mokhlis, S. (2009). Relevancy and measurement of religiosity in consumer behavior research. International Business Research, 2(3), 75-84.

Mukhtar, A., \& Mohsin Butt, M. (2012). Intention to choose Halal products: the role of religiosity. Journal of Islamic Marketing, 3(2), 108-120.

Rahayu, Y. S. (2015). Muslim Customer Perceived Value (MCPV) and Its Effect on Customer Satisfaction of Islamic Banking in Malang City. Proceedings. International Conference of Islamic Economics and Business (ICONIES). UIN Maulana Malik Ibrahim Malang.

Rahayu, Y. S. (2018). The Role Of Religiosity On The Influence Of Muslim Customer Perceived Value To Customer Satisfaction Of Islamic Banking. Proceedings. 1st International Conference on Halal Tourism, Products, and Services.

Rahman, M. S., Abdel Fattah, F. A. M., Zaman, M., \& Hassan, H. (2018). Customer's patronage decision toward health insurance products: mediation and multi-group moderation analysis. Asia Pacific Journal of Marketing and Logistics, 30(1), 62-83.

Rasheed, F. A., \& Abadi, M. F. (2014). Impact of service quality, trust and perceived value on customer loyalty in Malaysia services industries. Procedia-Social and Behavioral Sciences, 164, 298-304.

Rehman, A. U., \& Shahbaz Shabbir, M. (2010). The relationship between religiosity and new product adoption. Journal of Islamic Marketing, 1(1), 63-69.

Saputro, D. K. (2013). Pengaruh Perceived Quality, Perceived Sacrifice dan Perceived Value terhadap Customer Satisfaction di Informa Innovative Furnishing Pakuwon City Surabaya. Jurnal Strategi Pemasaran, 1(1).

Souiden, N., \& Rani, M. (2015). Consumer attitudes and purchase intentions toward Islamic banks: the influence of religiosity. International Journal of Bank Marketing, 33(2), 143-161.

Widiarso, W. (2011). The Relationship between Perceived Value, Customer Satisfaction, and Corporate Image with Brand Loyalty, Repurchase Intention, and Word of Mouth (Case Study on Blackberry mobile users in Surakarta City). Other thesis, Universitas Sebelas Maret.

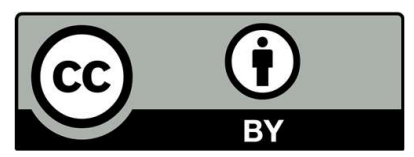

(C) 2020 by the authors; licensee Growing Science, Canada. This is an open access article distributed under the terms and conditions of the Creative Commons Attribution (CC-BY) license (http://creativecommons.org/licenses/by/4.0/). 